\title{
Vibrio mimicus
}

National Cancer Institute

\section{Source}

National Cancer Institute. Vibrio mimicus. NCI Thesaurus. Code C86845.

A species of facultatively anaerobic, Gram negative, curved rod shaped bacteria assigned to the phylum Proteobacteria. This species is motile, oxidase positive, lipase negative, hemolytic, cannot use sucrose as a carbon source and does not require salt for growth. V. mimicus is a found in marine and fresh water environments and is a pathogen that causes gastroenteritis. 